\title{
Tumor Susceptibility Gene 101 Protein
}

National Cancer Institute

\section{Source}

National Cancer Institute. Tumor Susceptibility Gene 101 Protein. NCI Thesaurus. Code C21237.

Tumor susceptibility gene 101 protein (390 aa, $44 \mathrm{kDa}$ ) is encoded by the human TSG101 gene. This protein is involved in both the binding and transport of ubiquitinated proteins. 